[Agr. Biol. Chem., Vol. 26, No. 9, p. 635, 1962]

\title{
On the Lysine and Threonine Containing Peptides Excreted in the Urine of Rats Fed on a Polished Rice Diet
}

Sir:

In the previous paper we reported that considerable amount of lysine and threonine was excreted in the urine of rats fed on rice protein and thereby a substantial portion of the amino acids was in conjugate form ${ }^{1}$. Subsequently, qualitative analysis of this conjugate amino acids revealed that the urine from the rats fed on rice protein contained a great quantities of conjugate form threonine $^{2,3)}$.

In this paper, we isolated peptides from the urine of rats fed on $10 \%$ rice protein diet by ion exchange column chromatography (Dowex-50w $\times 2$ ) and the quantities of lysine and threonine in peptides were measured by microbioassay method. Next, the isolated peptides was subjected to enzymic hydrolysis for 24 hours each pepsin and pancreatic enzymes, then the behaviour of its peptides to proteolytic enzymes was observed.

As the result, shown in Table $I, 7$ peptides

TABle I. Lysine AND Threonine QUANTITY IN THE PEPTIDES FROM THE URINE OF RAT FFD ON RICE DIET

\begin{tabular}{|c|c|c|c|c|}
\hline \multirow{3}{*}{$\begin{array}{l}\text { Pept. } \\
\text { No. }\end{array}$} & \multicolumn{2}{|c|}{ Lysine } & \multirow{2}{*}{\multicolumn{2}{|c|}{ Threonine }} \\
\hline & Content & Fycreted & & \\
\hline & $\mathrm{mg}$ & $\%$ & $\mathrm{mg}$ & $\%$ \\
\hline 1 & 1.4 & 1.27 & 1.1 & 1.57 \\
\hline 2 & 1.8 & 1.63 & 2.1 & 3.00 \\
\hline 3 & non & non & 1.0 & 1.42 \\
\hline 4 & 0.9 & 0.81 & 1.1 & 1.57 \\
\hline 5 & non & non & 1.5 & 2. 14 \\
\hline 6 & non & non & 0.9 & 1.28 \\
\hline 7 & 1.00 & 0.90 & 2.7 & 3.85 \\
\hline
\end{tabular}

1) Y. Nonaka and H. Ariyama, Tohoku J. Agr. Res., 12, 201 (1961).

2) Y. Nonaka and H. Ariyama, This Journal, 25, 731 (1961).

3) Y. Nonaka and H. Ariyama, Tohoku J. Agr. Res., 12, 291 were found to contain threonine which amounted respectively to $1.3,1.4,1.6,1.6,2.1$, 3.0 and $3.9 \%$ of its original threonine quantity eaten by the rats. On the other hand, 4 peptides contained lysine, these peptides were found to retain the amounts of lysine which were respectively equal to $0.8,0.9,1.3$ and $1.6 \%$ of lysine. Meanwhile 4 peptides contained both lysine and threonine.

And, these 7 threonine containing peptides were subjected to enzymic hydrolysis for 24 hours with pepsin in $\mathrm{pH} 2.0$ at $37^{\circ} \mathrm{C}$, thereafter, the pancreatic hydrolysis was carried out for 24 hours in $\mathrm{pH} 8.0$ at $37^{\circ} \mathrm{C}$. By the proteolytic enzymes, these 7 peptides were not cleavaged wholly under these conditions. From this result, it seems that these isolated peptides from the urine of the rats fed on rice diet are resistant to enzymatic hydrolysis.

Moreover, the N-terminal amino acid of these isolated peptides was determined by the Sanger's DNP-method ${ }^{4)}$. As the results, all of these peptides have alanine as the $\mathrm{N}$ terminal amino acid. The amino acids sequence of these peptides is being undertaken and the results will be reported at another occasion.

\section{Yoshimi Nonaka}

Hisashi Ariyama

Department of Food Chemistry, Faculty of Agriculture, Tohoku University

Received June 21, 1962

4) F. Sanger "Advances in Protein Chemistry", Academic Press, 1952, Vol. 7, p. 1; J.I. Harris, "Analytical methods of Protein Chemistry ", Pergamon Press, 1960, Vol. 2, p. 424. 